\title{
ANALISIS FINANSIAL USAHA DODOL SALAK (STUDI KASUS: UD MANDIRI DI DESA PANGU SATU KECAMATAN RATAHAN TIMUR KABUPATEN MINAHASA TENGGARA)
}

\author{
Kathleen Iin Grace Sagay \\ Agnes Estephina Loho \\ Melissa Lady Gisela Tarore
}

\begin{tabular}{ll}
\hline Naskah diterima melalui Website Jurnal Ilmiah agrisosioekonomi@unsrat.ac.id & : Rabu, 24 April 2019 \\
Disetujui diterbitkan & $:$ Jumat, 26 April 2019 \\
\hline
\end{tabular}

\begin{abstract}
The objective of this research is to analyze the level of financial feasibility of dodol "UD Mandiri" in Pangu Satu Village, Ratahan Timur Sub-District, Southeast Minahasa Regency. This research was conducted from November 2018 to April 2019. Research Methods Case Study. The data used are primary data and secondary data. Primary data is obtained from direct interviews with business owners UD Mandiri. Whereas secondary data is obtained from companies, books available at local bookstores and on the internet such as Google Scholar to access articles from various scientific journals and theses from other universities relating to the topic of this research are mainly concerned with financial analysis.Analysis of existing data using qualitative methods and quantitative methods. Qualitative methods are carried out to find out the dodol business characteristics that are presented in non-financial aspects in descriptive form, tables, charts or images, graphics such as process/production aspects, marketing aspects, legal aspects, environmental aspects, environmental aspects. Quantitative methods uses quantitative numbers regarding financial feasibility such as Net Present Value (NPV), Net B / C Ratio, Internal Rate Return (IRR), Payback Period (PP).The research result showed by using its own capital, UD Mandiri salak dodol business is declared feasible with an NPV value of Rp103.045.440, IRR (Internal Rate Return) or investment return of 60\%, more than the UKM interest rate ( $6 \%$ ) and Net B / C Ratio of 1,012, greater than one and payback period for two years. ${ }^{* j \mathrm{jkd}+\mathrm{erprm} *}$
\end{abstract}

Keywords: Financial analysis, Net Present Value (NPV), Net B/C Ratio, Internal Rate Return (IRR), Payback Period (PP), Dodol Salak Business

\begin{abstract}
ABSTRAK
Penelitian ini bertujuan untuk untuk menganalisis tingkat kelayakan finansial dodol salak "UD Mandiri" di Desa Pangu Satu Kecamatan Ratahan Timur Kabupaten Minahasa Tenggara. Penelitian ini dilakukan bulan November 2018 - April 2019. Metode Penelitian Studi Kasus. Data yang digunakan adalah data primer dan data sekunder. Data primer diperoleh dari wawancara langsung dengan pemilik usaha UD Mandiri. Sedangkan data sekunder diperoleh dari perusahaan, buku-buku yang tersedia di toko buku lokal dan di internet seperti google cendekia untuk mengakses artikel dari berbagai jurnal ilmiah dan skripsi dari perguruan tinggi lain yang berkaitan dengan topik penelitian ini terutama menyangkut analisis finansial. Analisis yang digunakan Analisis Deskriptif dilakukan untuk mengetahui karakteristik usaha dodol yang disajikan pada aspek-aspek non finansial seperti aspek proses/produksi, aspek pemasaran, aspek hukum, aspek lingkungan, aspek lingkungan. Untuk mengetahui aspek finansial digunakan Analisis Kuantitatif mengenai kelayakan finansial seperti Net Present Value (NPV), Net B/C Ratio, Internal Rate Return (IRR), Payback Period (PP). Hasil analisis kelayakan finansial menunjukkan bahwa dengan menggunakan modal sendiri, Usaha dodol salak UD Mandiri dinyatakan layak dilaksanakan dengan nilai NPV sebesar Rp103.045.440, IRR (Internal Rate Return) atau tingkat pengembalian investasi sebesar $60 \%$, lebih dari tingkat suku bunga UKM (6\%) dan Net B/C Ratio sebesar 1,012 lebih besar dari satu dan payback period selama dua tahun. ${ }^{*}$ inkd+erprm*
\end{abstract}

Kata kunci: Analisis Finansial, Net Present Value (NPV), Net B/C Ratio, Internal Rate Return (IRR), Payback Period (PP), Usaha Dodol Salak 


\section{PENDAHULUAN}

\section{Latar Belakang}

Sektor pertanian merupakan salah satu sektor yang mendorong perekonomian nasional. Sektor pertanian meliputi beberapa sub sektor yang terdiri dari sub sektor perikanan, peternakan, perkebunan, kehutanan dan holtikultura. Sub sektor holtikultura telah secara nyata dalam mendukung perekonomian nasional, baik dalam penyediaan produk pangan, kesehatan, dan kosmetika, perdagangan, penciptaan produk domestik bruto maupun penyerapan tenaga kerja (Badan Pusat Statistik, 2016). Buah-buahan merupakan bagian dari sub sektor holtikultura yang dapat memiliki potensi untuk dikembangkan, salah satunya yaitu buah salak.

Propinsi Sulawesi Utara memiliki beberapa daerah yang memproduksi buah salak, salah satunya Kabupaten Minahasa Tenggara Kecamatan Ratahan Timur memiliki beberapa desa yang dikenal sebagai sentra produksi salak yaitu Desa Pangu. Ditinjau dari produktivitasnya, desa sentra penghasil buah salak di Kecamatan Ratahan Timur terdapat tiga desa yaitu Desa Pangu, Desa Pangu Satu dan Desa Pangu Dua. Desa Pangu Satu memiliki tingkat produksi 1.650 ton/tahun dengan luas 220 ha.

Berdasarkan studi pendahuluan di lokasi penelitian, salak biasanya hanya dijual langsung di kios-kios (tempat persinggahan) oleh masyarakat Desa Pangu. Salak belum diolah menjadi produk yang bernilai tinggi. Ketersediaan bahan baku salak yang melimpah di Desa Pangu Satu terlihat dari hasil studi pendahuluan di lokasi penelitian dan juga berdasarkan hasil penelitian Palit (2017) yaitu sekitar $500 \mathrm{~kg}$ buah salak terbuang setiap bulannya karena tidak memenuhi syarat untuk dijual di Supermarket.

UD Mandiri adalah salah satu UKM (Usaha Kecil Menengah) yang terdapat di desa Pangu Satu dan merupakan satu-satunya industri rumah tangga yang masih bertahan dalam mengolah salak menjadi dodol salak. Dilihat dari segi waktu, usaha ini telah dirintis dari sejak 2004 dan memulai produksi dodol salak pada tahun 2006, lebih dari sepuluh tahun bertahan dalam menjalankan usahanya.

Usaha dodol salak UD Mandiri diawali dengan adanya bantuan pelatihan dan dana dari Dinas Perindustrian dan Perdagangan dalam rangka merintis usaha pengolahan dodol salak pada tahun 2006. Pada tahun 2010 dan 2012, UD Mandiri mengadakan penambahan modal lewat pinjaman pada bank BRI dengan jangka waktu pinjaman masing-masing dua tahun dikarenakan membutuhkan permodalan yang kuat dalam rangka peningkatan produksi. UD Mandiri membutuhkan investasi jangka panjang untuk melaksanakan berbagai aktivitas.

Menurut Wijaya (2017), perusahaan memerlukan prosedur guna menganalisis dan memilih investasi dengan tepat melalui penganggaran modal. Penganggaran modal adalah proses mengevaluasi dan memilih investasi jangka panjang sesuai dengan sasaran perusahaan untuk memaksimalkan nilai perusahaan.

Analisis finansial pada usaha dodol salak UD Mandiri perlu dilakukan karena belum dikaji secara mendalam dari segi finansialnya. Tujuan analisis finansial adalah menentukan apakah perusahaan secara keseluruhan finansial akan dapat hidup, artinya akan dapat memenuhi kewajiban finansialnya, menghasilkan laba yang pantas bagi modal yang diinvestasikan, dan dalam kasus-kasus tertentu hasilnya dapat memberi sumbangan kepada biaya investasi untuk waktu-waktu yang akan datang (Kadariaah, 2001 dalam Soemingkar, 2014).

Berdasarkan hal tersebut, penulis ingin meneliti apakah usaha UD Mandiri di Desa Pangu Satu Kecamatan Ratahan Timur Kabupaten Minahasa Tenggara dikatakan layak atau tidak secara finansial sehingga dapat memberikan pengembalian modal yang menguntungkan.

\section{Rumusan Masalah}

Berdasarkan latar belakang yang telah dikemukakan maka permasalahan dalam penelitian ini adalah bagaimana kelayakan finansial usaha dodol salak "UD Mandiri" di Desa Pangu Satu Kecamatan Ratahan Timur Kabupaten Minahasa Tenggara? 


\section{Tujuan Penelitian}

Berdasarkan masalah yang telah dikemukakan maka tujuan penelitian ini, yaitu untuk menganalisis tingkat kelayakan finansial dodol salak "UD Mandiri" di Desa Pangu Satu Kecamatan Ratahan Timur Kabupaten Minahasa Tenggara.

\section{Manfaat Penelitian}

1. Peneliti, menjadi pembelajaran dalam menerapkan teori dan konsep tentang bisnis atau usaha di bidang agribisnis.

2. Pelaku usaha, memberikan informasi mengenai kelayakan usaha dan dapat sebagai bahan pertimbangan untuk pengambilan keputusan mengenai pengembangan usaha mendatang.

3. Pembaca, sebagai bahan referensi dalam pengembangan ilmu pengetahuan untuk penulisan penelitian selanjutnya.

4. Investor dan lembaga keuangan, penelitian ini dapat dijadikan dasar dalam penanaman modal pada usaha dodol salak.

\section{METODE PENELITIAN}

\section{Lokasi dan Waktu Penelitian}

Penelitian ini dilaksanakan pada UD Mandiri di Desa Pangu Satu Kecamatan Ratahan Timur Kabupaten Minahasa Selatan sebagai usaha dodol salak. Penelitian ini dilakukan selama dari bulan November 2018 April 2019.

\section{Jenis dan Sumber Data}

Data yang dipakai dalam penelitian ini adalah data primer dan data sekunder. Data primer merupakan data mentah yang diambil oleh peneliti di lapangan langsung dari sumbernya yaitu pemilik usaha dan tenaga kerja dodol salak UD Mandiri di Desa Pangu Satu Kecamatan Ratahan Timur Kabupaten Minahasa Selatan. Data ini diperoleh dari wawancara secara langsung, sedangkan data sekunder merupakan data yang diperoleh dari instansi pemerintah, BPS (Badan Pusat Statistik), Bank Indonesia, Pemerintah Desa. Metode penelitian yang digunakan studi kasus.

\section{Metode Pengumpulan Data}

Metode pengumpulan data yang digunakan dalam penelitian ini adalah sebagai berikut :

1) Observasi

Teknik observasi adalah teknik pengumpulan data yang dilakukan dengan mengadakan pengamatan langsung terhadap objek yang diteliti sehingga didapatkan gambaran yang jelas mengenai objek yang diteliti tersebut.

2) Wawancara

Teknik wawancara merupakan teknik pengumpulan data yang dilakukan dengan cara tanya jawab tatap muka antara peneliti dengan responden berdasarkan daftar pertanyaan (quisioner) yang telah dipersiapkan sebelumnya.

3) Pencatatan

Teknik pencatatan merupakan teknik pengumpulan data yang dilakukan dengan cara mencatat hasil wawancara pada daftar pertanyaan (quisioner) dan mencatat data sekunder dari instansi pemerintah atau lembaga yang terkait dengan penelitian ini.

\section{Konsep Pengukuran Variabel}

Jenis data primer untuk analisis kuantitatif yang diperoleh menggunakan data tahunan dari Tahun 2015-2018 yaitu:

a. Biaya investasi (Rp) adalah biaya yang dikeluarkan untuk memulai usaha berupa bangunan, pembelian mesin dan peralatan produksi.

b. Biaya Reinvestasi adalah biaya yang dikeluarkan untuk pembelian alat produksi yang melewati batas umur ekonomis.

c. Biaya Penyusutan Alat

d. Biaya Nilai sisa

e. Untuk mengetahui besarnya penghasilan dapat diperoleh dari penjualan total kepada para pembeli selama periode bersangkutan. Penjualan ini merupakan sumber penghasilan utama bagi perusahaan. (Swastha dan Sukotjo, 2012).

Penjualan = Jumlah produk atau Quantity (Q) x Harga atau Price (P)

Penjualan dodol salak adalah hasil kali antara harga jual produk per kemasan $(\mathrm{Rp})$ dan jumlah produk per kemasan yang 
dihasilkan (X) per tahun. Harga jual adalah harga penjualan dodol salak dinyatakan dalam Rp/kemasan. Jumlah produk adalah dodol salak yang diproduksi dalam satuan kemasan per tahun.

f. Laba bersih dapat diperoleh dari seluruh penghasilan dikurangi seluruh biaya. Besarnya laba bersih yang dapat dicapai akan menjadi ukuran sukses bagi perusahaan (Swastha dan Sukotjo, 2012).

g. Biaya total adalah biaya tetap ditambah dengan biaya variabel.

h. Biaya tetap (Rp) yaitu semua jenis biaya yang besar-kecilnya tidak tergantung pada besar-kecilnya produksi. Biaya tetap antara lain biaya listrik, pajak, dan biaya telekomunikasi.

i. Biaya variabel (Rp) yaitu biaya besarkecilnya berhubungan dengan besarkecilnya produksi antara lain biaya bahanbahan produksi (Rp/Satuan), biaya kemasan (Rp/kemasan), biaya untuk gaji tenaga kerja (Rp/Bagian), dan biaya transportasi (Rp).

Analisis Deskriptif digunakan data primer yaitu

a. Gambaran umum usaha: sejarah, bentuk usaha, struktur organisasi.

b. Aspek teknis dan produksi: lokasi, alat dan bahan yang digunakan, proses produksi, layout.

c. Aspek sumber daya manusia: jumlah tenaga kerja, pendidikan terakhir tenaga kerja, sistem penggajian.

d. Aspek lingkungan: dampak terhadap lingkungan sekitar.

e. Aspek pemasaran: produk (spesifikasi produk, harga produk, penjualan produk per tahun), distribusi, dan promosi.

Data primer diperoleh dengan hasil pengamatan di lapangan dan wawancara dengan pihak terkait. Data sekunder diperoleh dari instansi pemerintah setempat yaitu jumlah produksi buah salak per tahun, luas lahan, peta desa, dokumen dari pemilik dari pihak usaha berupa aspek hukum (perizinan), jumlah produksi kemasan dodol salak Tahun 20152018, jumlah penggunaan bahan-bahan produksi Tahun 2015-2018 dan beberapa pustaka yang terkait dengan penelitian ini.

\section{Analisis Data}

Analisis data yang ada menggunakan analisis deskriptif dan analisis kuantitatif. Analisis deskriptif dilakukan untuk mengetahui karakteristik usaha dodol yang disajikan pada aspek-aspek non finansial dalam bentuk deskriptif, tabel, bagan atau gambar, grafik seperti aspek proses/produksi, aspek pemasaran, aspek hukum, aspek lingkungan, aspek lingkungan. Untuk mengetahui aspek finansial digunakan analisis kuantitatif dengan penggunaan angka kuantitatif mengenai kelayakan finansial seperti Net Present Value (NPV), Net B/C Ratio, Internal Rate Return (IRR), Payback Period (PP).

a. Net Present Value (NPV)

Menurut Nurmalina dkk (2014) dalam Insyafli (2017) bahwa Net Present Value (NPV) atau nilai sekarang merupakan selisih antara total present value manfaat bersih dengan total present value biaya. Suatu bisnis dikatakan layak jika total present value manfaat yang diterima melebihi total present value biaya yang dikeluarkan atau NPV $>0$, jika kurang dari nol maka bisnis tersebut dinyatakan tidak layak. NPV dinyatakan dalam satuan rupiah. Secara matematis NPV dapat dirumuskan sebagai berikut:

$N P V=\sum_{\mathrm{t}=0 / 1}^{\mathrm{n}} \frac{\mathrm{B}_{\mathrm{t}-\mathrm{C}_{\mathrm{t}}}}{(1+\mathrm{i})^{\mathrm{t}}}$

Dimana :

$\mathrm{Bt}$ : Manfaat pada tahun $\mathrm{t}$

$\mathrm{Ct}$ : Biaya pada tahun $\mathrm{t}$

$\mathrm{t}$ : Tahun kegiatan bisnis $(\mathrm{t}=0,1,2,3, \ldots, \mathrm{n})$, tahun awal bisa tahun 0 atau tahun 1 tergantung karakteristik bisnisnya

i : Tingkat Discout Rate/suku bunga yang digunakan

$\frac{1}{(1+i)^{t}}$ : discount factor $(\mathrm{DF})$ pada tahun $\mathrm{t}$

Kriteria Penilaian Kelayakan Finansial

Menurut Subagyo (2008) dalam Rasmiati (2016), Kriteria penilaian kelayakan finansial sebagai berikut:

1. $N P V>0$, artinya usaha sudah dinyatakan menguntungkan, dengan kata lain jika $N V P$ lebih besar dari nol maka rencana investasi diterima dan dapat dilaksanakan. Artinya usaha layak untuk dijalankan. 
2. $N P V=0$, artinya usaha mampu mengembalikan persis sebesar modal sosial opportunity cost faktor produksi normal, dengan kata lain usaha tersebut tidak untung dan tidak merugi. Artinya usaha masih dalam pertimbangan untuk di jalankan.

3. $N P V<0$, artinya usaha tidak menghasilkan nilai biaya yang dipergunakan, dengan kata lain jika $N V P$ lebih kecil dari nol maka rencana investasi ditolak atau sebaiknya tidak diteruskan. Artinya usaha tidak layak untuk di jalankan.

Untuk menghitung $N P V$ dari suatu usaha diperlukan data tentang:

1) jumlah investasi yang dikeluarkan, dan

2) arus kas bersih per tahun sesuai dengan umur ekonomis dari alat-alat produksi yang digunakan untuk menjalankan usaha yang bersangkutan dan suku bunga yang relevan (Gray dkk, 2007 dalam Rasmiati 2016).

b. Internal Rate of Return (IRR)

Internal Rate of Return (IRR) menilai kelayakan usaha berdasarkan tingkat pengembalian bisnis terhadap investasi yang ditanamkan. Hasil perhitungan IRR dinyatakan dalam satuan persen (\%). Perhitungan IRR umumnya dengan menggunakan metode interpolasi antara tingkat discount rate yang menghasilkan NPV positif dengan tingkat discount rate yang menghasilkan NPV negatif. Suatu usaha dapat dikatakan layak jika IRR yang dihasilkan lebih besar dari discount ratenya. Secara matematis, IRR dapat dihitung dengan menggunakan rumus berikut (Nurmalina dkk, 2014 dalam Masithah 2018).

$I R R=\mathrm{i}_{1}+\frac{\mathrm{NPV}_{1}}{\mathrm{NPV}_{1}-\mathrm{NPV}_{2}} \times\left(\mathrm{i}_{2}-\mathrm{i}_{1}\right)$

Keterangan:

$\mathrm{i}_{1}=$ Discount rate yang menghasilkan NPV positif

$\mathrm{i}_{2}=$ Discount rate yang menghasilkan NPV negatif

$N P V_{1}=N P V$ positif

$N P V_{2}=N P V$ negatif

c. Payback Period (PP)

Payback period (PP) ini mencoba mengukur seberapa cepat investasi bisa kembali. Usaha yang payback period-nya cepat maka akan dipilih. Secara matematis, $P P$ dapat dihitung dengan menggunakan rumus berikut (Nurmalina dkk, 2014 dalam Masithah 2018).
Payback Period $=\frac{\mathrm{I}}{\mathrm{Ab}}$

Keterangan:

$\mathrm{I}$ = Besarnya biaya investasi yang diperlukan

$\mathrm{Ab}=$ Manfaat bersih yang dapat diperoleh setiap tahunnya

\section{d. Net Benefit//Cost Ratio}

$\mathrm{Net} B / C$ ratio adalah rasio antara manfaat bersih yang bernilai positif (menguntungkan) dengan manfaat bersih yang bernilai negatif (merugikan). Secara matematis, Net $\mathrm{B} / \mathrm{C}$ ratio dapat dihitung dengan menggunakan rumus berikut (Nurmalina et al. 2014 dalam Masitha 2018).

Net $\mathrm{B} / \mathrm{C}=\frac{\sum_{\mathrm{t}=1}^{\mathrm{n}} \frac{\mathrm{B}_{\mathrm{t}}-C_{\mathrm{t}}}{(1+\mathrm{i})^{\mathrm{t}}}}{\sum_{\mathrm{t}=1}^{\mathrm{n}} \frac{\mathrm{B}_{\mathrm{t}}-C_{\mathrm{t}}}{(1+\mathrm{i})^{\mathrm{t}}}} \quad \frac{\left(B_{t}-C_{t}\right)>0}{\left(B_{t}-C_{t}\right)<0}$

Keterangan:

$\mathrm{Bt}=$ Manfaat pada tahun $\mathrm{t}$

$\mathrm{Ct}=$ Biaya pada tahun $\mathrm{t}$

$\mathrm{t}=$ Periode

$\mathrm{i}=$ Tingkat discount rate $(\%)$

Kriteria investasi berdasarkan Net B/C Ratio adalah (Ibrahim, 2003 dalam Rasmiati 2016)

1. Net $B / C>1$, maka usaha menguntungkan, dengan kata lain jika $B / C$ lebih besar dari 1 , maka usaha dikatakan efisien karena keuntungan yang diperoleh lebih besar dari jumlah biaya yang dikeluarkan. Artinya usaha layak untuk di jalankan.

2. Net $B / C=1$, maka usaha berada pada titik impas, dengan kata lain jika $B / C$ sama dengan 1, maka usaha dikatakan impas karena keuntungan yang diperoleh sama dengan jumlah biaya yang dikeluarkan. Artinya usaha masih dalam pertimbangan untuk di jalankan.

3. Net $B / C<1$, maka usaha merugikan, dengan kata lain jika $B / C$ lebih kecil dari 1, maka usaha dikatakan tidak efisien karena keuntungan yang diperoleh lebih kecil dari jumlah biaya yang dikeluarkan. Artinya usaha belum layak untuk dijalankan.

\section{HASIL DAN PEMBAHASAN}

\section{Sejarah Berdirinya Perusahaan}

UD Mandiri merupakan satu-satunya pelaku usaha yang masih bertahan bergerak di bidang pengolahan dodol yang berbahan dasar buah salak di Desa Pangu Satu. Usaha ini berdiri pada tahun 2004 dengan pemiliknya 
adalah Bapak Arce Sengkey. Pada awalnya berdirinya, pemilik memulai dengan memproduksi gula merah dan gula semut aren serta sebagai petani pengumpul buah salak dan hanya menjual salak segar tanpa diolah terlebih dahulu. Pada tahun 2006 tepatnya pemilik memulai memproduksi dodol salak dengan adanya bantuan pelatihan dari Dinas Perindustrian dan Perdagangan (Disperindag) untuk mengolah salak menjadi dodol dan memiliki nilai tambah yang lebih dari sebelum diolah. Dengan adanya pelatihan tersebut maka banyak petani salak di Desa Pangu Satu beralih untuk tidak hanya menjual salak segar namun juga menjual dodol salak. Petani salak menjual dodol salak hanya di area Desa Pangu Satu. Upaya yang dilakukan untuk Pemilik UD Mandiri untuk dapat bertahan dalam persaingan yaitu perluasan pasar yaitu dengan penjualan dodol salak sampai di luar Desa Pangu Satu.

\section{Produk \& Harga \\ Aspek Pemasaran}

Spesifikasi Kemasan Dodol Salak

Berikut ini terdapat spesifikasi kemasan dodol salak UD Mandiri pada Tabel 1.

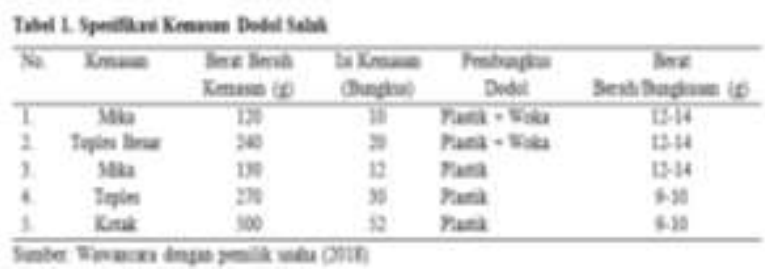

Produk dodol salak UD Mandiri saat ini terdapat empat kemasan yaitu kemasan mika pembungkus plastik + daun janur (woka), kemasan mika pembungkus plastic serta kemasan toples bulat pembungkus plastik, dan kemasan kotak pembungkus plastik. Sedangkan kemasan toples besar woka ini hanya diproduksi pada tahun 2017.

\section{Harga}

Produk dodol salak memiliki harga yang berbeda, tergantung dengan kemasan. Untuk produk dodol salak kemasan mika dengan pembungkus daun janur (woka) dan kemasan mika dengan pembungkus plastik dijual dengan harga Rp 7.000 per kemasan. Sedangkan untuk kemasan toples sebesar Rp 25.000, toples besar woka Rp 20.000 dan Rp 40.000 kemasan kotak plastik.

\section{Aspek Teknis \& Produksi}

Lokasi pabrik terletak tidak jauh dari jalan raya yaitu sekitar satu kilometer dan sekitar dua kilometer dari perkebunan salak petani setempat sehingga tidak mendapat kendala dalam pasokan bahan baku.

Dodol salak yang dihasilkan oleh usaha ini menggunakan bahan baku daging salak, sedangkan bahan penolongnya berupa santan kelapa, tepung beras, gula pasir, gula aren, vanili bubuk, dan garam.

Alat-alat yang digunakan mudah didapatkan dan biasa digunakan masyarakat pada umumnya serta teknologi yang digunakan masih sangat sederhana dan tradisional.

Proses pengolahan dodol salak terdiri tahap persiapan dan tahap pemasakan.

\section{Aspek Hukum}

Usaha ini telah terdaftar sebagai Usaha Dagang dengan memiliki TDP, TDI, SIUP, Izin Usaha Industri (IUI) dan (IMB). Perizinan lainnya berkaitan dengan kualitas produk dari BPOM dengan sertifikasi PIRT.

\section{Aspek Manajemen dan Sumber Daya Manusia}

Sumber daya manusia pada usaha ini berjumlah sepuluh orang sebagai pekerja tetap yang terdiri dari dua tenaga kerja dari dalam keluarga dan delapan tenaga kerja dari luar keluarga.

\section{Aspek Lingkungan}

Limbah dari usaha ini berupa biji salak yang dijual untuk diolah menjadi kopi sedangkan untuk kulit salak hanya dibuang dan belum mampu diolah menjadi produk yang bernilai.

\section{Aspek Finansial}

Kelayakan finansial UD Mandiri perlu dianalisis karena dari analisis finansial diperoleh informasi mengenai aliran kas dan kelayakan usaha. Aliran kas atau cash flow terdiri dari aliran kas masuk (inflow) dan aliran kas keluar (outflow). 


\section{Aliran Kas Masuk (Inflow)}

Inflow adalah aliran kas masuk bagi suatu usaha. Arus penerimaan UD Mandiri berasal dari nilai sisa dan penjualan dodol salak dari investasi yang ditanam perusahaan dalam memulai usahanya.

Nilai sisa adalah nilai dari suatu barang yang masih memiliki nilai pada saat umur proyek berakhir. Nilai sisa UD Mandiri sebesar Rp 55.000.000. Rincian nilai sisa UD Mandiri dapat dilihat pada Tabel 2.

Tabel 2. Nilai Sisa Usaha Dodol Salak UD Mandiri

\begin{tabular}{lll}
\hline No. & Komponen & Nilai (Rp) \\
\hline 1. & Bangunan Usaha & 15.000 .000 \\
2. & Kendaraan Pick-Up & 10.000 .000 \\
3. & Kendaraan Avanza & 30.000 .000 \\
\hline & Total & 55.000 .000 \\
\hline
\end{tabular}

Sumber: Data Primer (2019), diolah

\section{Penerimaan dari Penjualan Dodol Salak}

Penerimaan UD Mandiri dihitung dari perkalian antara harga masing-masing kemasan dengan jumlah produksi setiap kemasan yang dihasilkan setiap bulan dan ditotal per tahun. Penerimaan UD Mandiri digambarkan pada Tabel 3.

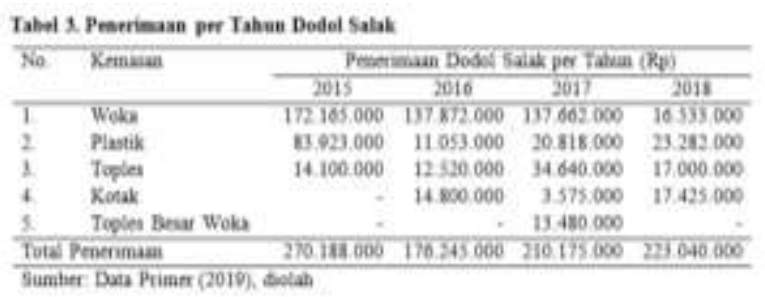

Penerimaan terbesar terdapat pada tahun 2015 sebesar Rp 270.188.000 dan penerimaan terendah pada tahun 2016 sebesar $\mathrm{Rp}$ 176.245.000. Penerimaan UD Mandiri tidak tetap pada kemasan kotak dan toples besar woka. Penerimaan dodol salak kemasan dodol toples terbesar pada tahun 2018 sebesar Rp 17.425.000. Sedangkan penerimaan dodol salak kemasan toples besar woka hanya pada tahun 2017 sebesar Rp 13.480.000. Penerimaan dodol salak pada kemasan woka terendah pada tahun 2017.

\section{Aliran Kas Keluar (Outflow)}

Komponen outflow pada usaha dodol salak UD Mandiri terdiri dari dua komponen biaya, yaitu biaya investasi dan biaya operasional.

\section{a. Biaya Investasi}

Biaya investasi adalah biaya yang dikeluarkan untuk membeli atau menjual tanah, bangunan, dan peralatan. Biaya investasi yang dikeluarkan pada awal usaha UD Mandiri yaitu terdiri dari bangunan usaha, biaya perizinan, transportasi (kendaraan), mesin dan peralatan serta biaya administrasi pada outlet-outlet souvenir. Rincian biaya investasi UD Mandiri dapat dilihat pada Tabel 4.

\begin{tabular}{|c|c|c|c|c|}
\hline $\mathrm{Na}$ & Kompousn & Stive & Immtah tait & Jumlah Baxy \\
\hline $\bar{t}$ & Banguaan wah & Chit & $t$ & 9000000 \\
\hline 2 & Biars Perizinatse & Chit & 4 & 7,100000 \\
\hline 3. & frangentas & Chin & 2 & $99,999.969$ \\
\hline 4. & stem & thit & 3 & 8500000 \\
\hline 5. & Pestan & Gait & 19 & 7975000 \\
\hline 5. & 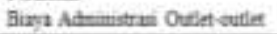 & Unit & 8 & 20000 \\
\hline Toel & & & & 213574099 \\
\hline
\end{tabular}

Biaya Investasi pada UD Mandiri terdiri dari bangunan usaha, biaya perizinan, transportasi, mesin, peralatan dan biaya administrasi outlet-outlet dengan total biaya sebesar Rp 213.374.999.

\section{b. Biaya Operasional}

Biaya operasional adalah biaya yang berkaitan dengan modal kerja untuk kegiatan operasional atau biaya yang diperlukan untuk menjalankan atau melaksanakan kegiatan barang modal dalam suatu proses sehingga menghasilkan produk yang diinginkan. Biaya operasional terbagi dua yaitu biaya tetap dan biaya variabel.

Biaya Tetap

Menurut Hanafie (2010), Biaya tetap adalah semua jenis biaya yang besar-kecilnya tidak bergantung pada besar-kecilnya produksi. Yang termasuk biaya tetap UD Mandiri adalah biaya listrik, pajak, pemasaran dengan Tabel 5 sebagai berikut

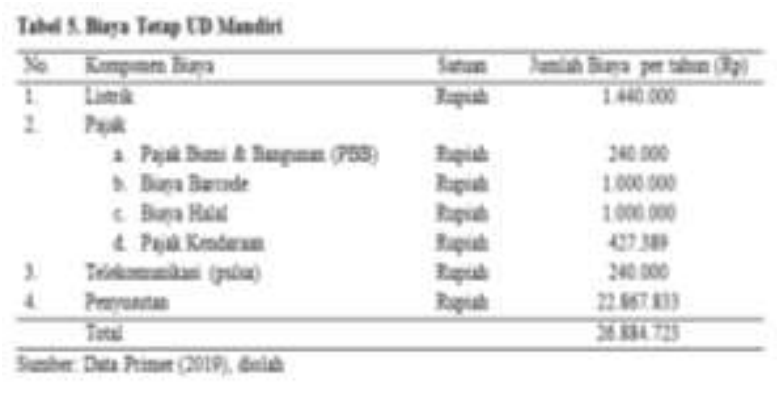


Biaya Penyusutan

Biaya penyusutan per tahun untuk masing-masing komponen investasi dapat dilihat pada Tabel 6 .

\begin{tabular}{|c|c|c|}
\hline No & Kompones Biaya & Biwa Peavusutan per Tahun (Rp) \\
\hline$t$ & Eangtman unaha & $4,450,000$ \\
\hline 2. & Kendarawi & 11.063 .333 \\
\hline 3. & Mesia & 4.106 .007 \\
\hline \multirow[t]{2}{*}{4} & Peralatan & 2.587 .833 \\
\hline & Total & 22.907 .833 \\
\hline
\end{tabular}

Biaya penyusutan dihitung berdasarkan metode garis lurus (straight line) sesuai dengan umur ekonomisnya. Dan total biaya penyusutan UD Mandiri dalam setahun yaitu sebesar Rp.22.867.833. Biaya penyusutan terbesar adalah biaya kendaraan sebesar Rp.11.663.333, dan biaya terendah pada peralatan sebesar Rp2.587.833. Biaya penyusutan dapat dilihat pada lampiran 3 . Biaya penyusutan pada UD Mandiri adalah biaya termasuk dalam biaya tetap. Pada perhitungan cashflow, biaya penyusutan tidak akan dimasukkan karena biaya penyusutan bukan termasuk dalam biaya yang dikeluarkan perusahaan secara langsung.

Biaya Variabel

Biaya variabel atau biaya tidak tetap yaitu biaya besar-kecilnya berhubungan langsung dengan besar-kecilnya produksi. Jumlah biaya variabel sama dengan jumlah faktor produksi variabel dikalikan dengan biaya faktor produksi. (Hanafie, 2010). Biaya Variabel pada UD Mandiri terdiri dari biaya bahan-bahan produksi, kemasan, gaji, dan transportasi dapat dilihatt pada Tabel 7 berikut.

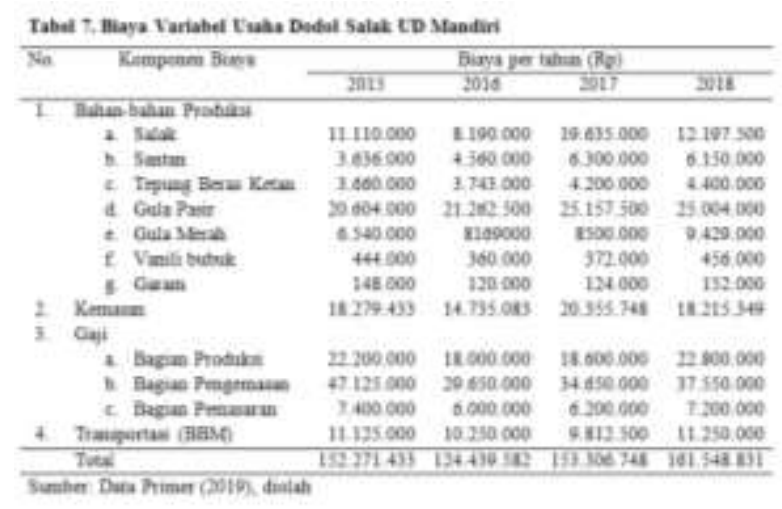

\section{Analisis Kriteria Investasi}

Analisis kriteria investasi digunakan untuk mengukur tingkat kelayakan usaha dodol salak UD Mandiri. Metode penilaian yang digunakan meliputi Net Present Value $(N P V)$, Internetal Rate of Return (IRR), Net Benefit-Cost (Net B/C) Ratio, dan Payback Period. Hasil investasi perusahaan dapat dilihat pada Tabel 8 .

Tabel 8. Nilai Kriteria Investasi Usaha Dodol Salak UD Mandiri

\begin{tabular}{llc}
\multicolumn{3}{c}{ Kriteria Investasi } \\
\hline No. & \multicolumn{1}{c}{ Nilai } \\
\hline 1. & Net Present Value (NPV) & Rp103.045.440 \\
2. & Internetal Rate of Return (IRR) & $60 \%$ \\
3. & Net Benefit-Cost (Net B/C) Ratio & 1,012 \\
4. & Payback Period & 2 Tahun \\
\hline
\end{tabular}

Sumber: Data Primer (2019), diolah

\section{Net Present Value (NPV)}

Berdasarkan Tabel 8 dapat dilihat UD Mandiri memiliki nilai NPV sebesar Rp 104.075.086 yang berarti usaha ini menerima keuntungan sebesar Rp 102.929.844 selama 4 tahun menurut nilai waktu uang sekarang dengan tingkat diskonto $6 \%$. Nilai tersebut menunujkkan bahwa usaha ini layak untuk dilanjutkan karena memiliki manfaat yang positif yaitu (NPV>0).

\section{Internal Rate of Return (IRR)}

Nilai IRR yang didapatkan hasil analisis adalah sebesar $60 \%$ dan lebih dari tingkat suku bunga $(6 \%)$ yang berarti usaha ini layak. Usaha UD Mandiri memberikan keuntungan lebih besar dari dibandingkan dengan mendepositokan modalnya di bank dengan suku bunga yang berlaku. Hasil analisis didapat melalui proses percobaan, atau trial and error process.

\section{Net B/C Ratio}

Net $B / C$ Ratio merupakan tingkat tambahan manfaat dari setiap tambahan biaya sebesar Rp 1,00. Net B/C dapat dirumuskan sebagai perbandingan antara nilai $N P V$ yang bernilai positif (sebagai pembilang) dengan $N P V$ yang bernilai negatif (sebagai penyebut). 
Nilai Net $B / C$ yang didapatkan dari hasil analisis adalah sebesar 1,14 artinya usaha ini layak dilanjutkan karena usaha ini menghasilkan nilai $\mathrm{Net} B / C$ yang lebih besar dari 1. Nilai Net $B / C \quad 1,012$ menujukkan bahwa setiap $\mathrm{Rp} 1$ biaya yang dikeluarkan akan menghasilkan keuntungan sebesar Rp1,012.

\section{Payback Period (PP)}

Payback Period (PP) adalah suatu periode yang diperlukan untuk menutup kembali pengeluaran investasi dengan menggunakan aliran kas.

Hasil Payback Period yaitu dua tahun yang artinya untuk mengembalikan nilai investasi usaha membutuhkan waktu dua tahun. Hal ini berarti perusahaan mampu mengembalikan investasinya sebelum umur proyek berakhir.

\section{KESIMPULAN DAN SARAN}

\section{Kesimpulan}

Hasil analisis deskriptif usaha dodol salak yaitu memiliki jangkauan pasar yang luas/tempat distribusi sekitar 30 outlet (aspek pemasaran), teknologi yang digunakan masih sangat sederhana dan tradisional, produksi dodol salak dengan kemasan mika, toples, kotak, toples besar (aspek teknis \& produksi), tidak memiliki kriteria khusus dalam mencari tenaga kerja dengan jumlah tenaga kerja sepuluh orang (aspek manajemen $\&$ sumber daya manusia), limbah berupa kulit dan biji salak (aspek lingkungan).

Hasil analisis kelayakan finansial dapat disimpulkan bahwa dengan usaha dodol salak UD Mandiri dinyatakan layak dilaksanakan/dilanjutkan dengan nilai NPV sebesar Rp103.045.440, IRR (Internal Rate Return) atau tingkat pengembalian investasi sebesar $60 \%$, lebih dari tingkat suku bunga pinjaman UKM (6\%) dan Net B/C Ratio sebesar 1,012 lebih besar dari satu dan payback period selama dua tahun.

\section{Saran}

1. Pemilik usaha tetap mengembangakan usaha dodol salak, karena usaha tersebut menguntungkan dari aspek finansialnya.

2. Investor dapat memberikan modal untuk investasi usaha dodol salak UD Mandiri, karena usaha ini layak dari aspek finansial.

3. Untuk masyarakat, usaha ini dapat dijadikan model percontohan bagi masyarakat yang ingin membuka usaha dodol salak.

\section{DAFTAR PUSTAKA}

Palit, Anisa. 2017. Strategi Pengembangan Agroindustri Dodol Salak Di Desa Pangu

Satu Kecamatan Ratahan. Skripsi Fakultas Pertanian. Universitas Sam Ratulangi Manado.

BPS. 2016. Statistik Tanaman Buah-buahan dan Sayuran Tahunan Tahun 2016. Badan Pusat Statistik Indonesia.

Hanafie, Rita. 2010. Pengantar Ekonomi Pertanian. Yogyakarta: 2010.

Insyafli. 2017. Analisis Kelayakan Finansial dan Pengambilan Keputusan Pola Usaha pada Peternakan Ayam Boiler. Skripsi Fakultas Ekonomi dan Manajemen. Institut Pertanian Bogor.

Masithah. 2018. Kelayakan Pengusahaan Buah Tin (Ficus carica) Kebun Jogja Ara Garden di Yogyakarta. Skripsi Ekonomi \& Manajemen. Institut Pertanian Bogor.

Rasmiati. 2016. Analisis Finansial pada Usaha Jamur Merang. Skripsi Fakultas Pertanian. Universitas Teuku Umar Aceh Barat.

Soemingkar. 2014. Analisis Finansial Industri Rumah Kayu CV. Rajawali Tunggal Perkasa Di Desa Woloaan 1 Utara Kec. Tomohon Barat. Skripsi Fakultas Pertanian. Universitas Sam Ratulangi Manado. 
Swastha dan Sukotjo. 2012. Pengantar Bisnis Modern. Yogyakarta: Liberty.
Wijaya. 2017. Manajemen Keuangan Berbasis IFRS Teori, Soal dan Pembahasan. Yogyakarta: Gava Media. 